\title{
THE DUTY TO CONTROL THE CONDUCT OF ANOTHER
}

\author{
FOWLER V. HARPER $\dagger$ AND POSEY M. KIME ††
}

\section{INTRODUCTION}

Whether a person is under a duty to make any effort to control the conduct of another to avoid harm to a third person presents a problem in the law of Torts which is generally treated as one of affirmative obligation. The distinction between misfeasance and mere non-feasance is an old one and, while the line is recognized as shadowy in places, it still affords a practical basis for analysis. Whether given conduct is to be described as the improper performance of proper acts or a failure to perform acts which should have been performed is the orthodox touchstone for deciding many tort cases. ${ }^{1}$ To be sure, this formula is capable of manipulation, and any given set of facts can be compressed to come within the concept of non-feasance or expanded to fit the mould of misfeasance. The trick is a simple one of selecting that point in the series of happenings from which the analysis is to start. $^{2}$ An accident at a level crossing, for example, may logically be regarded as the result of the mere failure of the engineer to sound a warning or make timely application of his brakes; or it can be regarded as the improper operation of the locomotive. But although the formula is thus superficial and inexact, the basic principles for determining duty are the same in all cases. A sounder basis for analysis is the relationship of the parties. If the conduct of the actor has brought him into a human relationship with another, of such character that sound social policy requires either some affirmative action or some precaution on his part to avoid harm, the duty to act or take the precaution is imposed by law. "Given a relation," says Judge Cardozo with characteristic insight, ${ }^{3}$

"involving in its existence a duty of care . . ., a tort may result as well from acts of omission as of commission in the fulfillment of the duty thus recognized by law. What we need to know is not so much the conduct to be avoided when the relation and its attendant duty are established as exist-

iProfessor of Law, Indiana University School of Law; author of A Treatise on THE LAW OF ToRTs (1933).

ti Judge of the Appellate Court of Indiana.

1. See BoHLen, Studies IN the LAW of Torts (1926) 33.

2. See Harper, LAW OF TorTs (1933) 204, \$ 81.

3. Moch Co., Inc. v. Rensselaer Water Co., 247 N. Y. $160,167,159$ N. E. 896 , 898 (1928). 
ing. What we need to know is the conduct that engenders the relation. It is here that the formula, however incomplete, has its value and significance."

Judge Cardozo has thus deftly pointed out the actual basis of policy for the distinction between misfeasance and non-feasance. The man who has undertaken a definite course of continuous action thus brings himself into relation with other human beings within the zone of possible danger, to an extent requiring that precaution against bodily harm to such persons which a reasonable man under the circumstances would take. If he fails to do so, this is characterized as misfeasance. In other words, an actor is always under the duty to see that other persons are not immediately exposed to an unreasonable risk from his acts. On the other hand, a previous course of action, not in itself creating risks to others, may have brought the actor into certain socially recognized relations with others which are of such a character as to require affirmative acts to protect them from risks which the person thus required to act had no part in creating. The failure to perform such an act is described as non-feasance. The situation is more easily comprehended by treating the latter situation as the only one depending upon the relationship of the parties. The principle is thus ordinarily formulated that while an actor is always bound to prevent his acts from creating an unreasonable risk to others, he is under the affirmative duty to act to prevent another from sustaining harm only when certain socially recognized relations exist which constitute the basis for the legal duty.

Accordingly, it may be said that there is ordinarily no general duty to act for the protection of others. As formulated in the Restatement of Torts," "The actor's realization that action on his part is necessary for another's aid or protection does not of itself impose upon him a duty to take such action." This principle would be applicable to the specific problem of the duty to control another's conduct to prevent harm to a third person. Certain situations there are, however, in which the social relationships of the parties are of such a character that the law imposes the affirmative duty upon one person to attempt to control another's conduct to avoid an unreasonable risk to a third person. There are two kinds of relationships which give rise to this duty. The relationship between the defendant and the person who threatens the harm to the third person may be such as to require the defendant to attempt to control the other's conduct. On the other hand, there may be a relationship between the defendant and the person exposed to harm which requires the defendant to af-

4. Torts Restatearent, Draft T. No. 4 (Am. L. Inst. 1929) § 192. 
ford protection from certain dangers including the conduct of others. It is the purpose of this article to consider a few situations in which this duty is present.

\section{Character of the Duty}

The cases which constitute the basis of this investigation disclose that the problem is primarily one of negligence. There is no duty to control another's conduct at the risk of the actor. The problem is not one of action or failure to act at peril. There is no obligation corresponding to the absolute duty imposed by common law so to control the activities of wild animals as to prevent, at all events, the animal from causing harm to another. ${ }^{5}$ The law might have been otherwise and drawn such an analogy; for obvious reasons, however, it has not done so. There are, for example, sufficient considerations for a less onerous duty on the part of a parent to control the conduct of his minor child, even though a vicious one, than for one who harbors a vicious animal to control the activities of the beast. A man is not required to harbor a wild animal and, if he chooses to do so, cannot complain that the common law imposes upon him the risk that the animal will exhibit its wild character and attack another. He may exercise all the care of which he is capable, but nevertheless be held for the unfortunate consequences of his conduct. Parents, on the other hand, are not able to exercise the same volition with respect to the rearing of a family, and while children may have many of the vicious propensities of animals, sufficient reliance is placed upon the veneer of civilization to reduce the recognizable risks to a point much lower than those involved in the harboring of animals.

Thus, the duty involved in controlling the conduct of human beings is at most the duty to exercise reasonable care for the prevention of harm to others. The risk against which the attempt to exercise control must be directed may be either action on the part of the other intended to harm a third person, or action on his part which constitutes negligence toward the third person. A parent, therefore, as will be seen, may be under a duty to exercise reasonable care so to control the conduct of his minor children as to prevent his child from intentionally attacking another or from so acting that its conduct constitutes a recognized and unreasonable risk of harm to the third person.

Another's Use of Defendant's Chattel in his Presence

The fact that another is using a defendant's chattel in the latter's pres-

5. May v. Burdett, 9 Q. B. 101 (1846); Hays v. Miller, 150 Ala. 621, 43 So. S1s (1907); Copley v. Wills, 152 S. W. 830 (Tex. Civ. App. 1913); Opelt v. Barnes Co., 41 Cal. App. 776, 183 Pac. 241 (1919). 
ence has, at least under certain circumstances, been regarded as a sufficient basis for an affirmative duty on the part of the defendant to control the conduct of the other in such a way as to prevent him from unduly endangering third persons. A number of cases involving the driving and operation of vehicles have seemingly involved this doctrine. ${ }^{6}$ One of the earliest cases involved the liability of the possessor of a horse and carriage who permitted a guest to drive the horses. ${ }^{7}$ Through the negligent driving of the guest while the possessor was in the carriage, an injury was caused to a third person. The possessor was held liable, not for the negligence of the driver, but apparently for his own fault in failing to exercise that care which was proper on his part to prevent the driver from being negligent. "He is the party in possession," said the court, "he is present, he has the actual control." A Pennsylvania case $^{9}$ involving a similar vehicle arrived at the same result, although the basis therefor was clearly that of master and servant. There the owner had permitted his guest to take the reins while he sat in the carriage with him. The court reasoned that since the owner had the choice of the person who should drive and, as owner, had the right to control his actions while driving and the right to retake the reins at any moment, he was liable for the driver's negligence as his master. ${ }^{10} \mathrm{~A}$ later English case, Sampson v. Aitchison, ${ }^{11}$ involved the application of the same reasoning to the driving of an automobile. Here a prospective purchaser desired her son's advice before buying the vehicle. The defendant's agent, a salesman in charge, took the prospective customer and her son for a demonstration and during the demonstration permitted the son to drive the car. The inexperienced son injured a traveler who brought an action against the defendant as owner of the vehicle. The court held the defendant liable on the ground that, being in possession of the automobile and thus in a position to direct and control its operation, it was chargeable with the negligence of the driver.

It is to be observed that in very few of these cases is the principle enunciated with that clarity which would indicate the difference between vicarious liability and liability for the defendant's own default. In

6. Sampson v. Aitchison, [1912] A. C. 844; Bell v. Jacobs, 261 Pa. 204, 104 Atl. 587 (1918); Kelly v. Thibodeau, 120 Me. 402, 115 Atl. 162 (1921); Pratt v. Patrick, [1924] 1 K. B. 488; Beaudoin v. Mahaney, 131 Me. 118, 159 Atl. 567 (1932); Wheeler v. Darmochwat, 280 Mass. 553, 183 N. E. 55 (1932).

7. Wheatley v. Patrick, 2 M. \& W. 650 (Eng. 1837).

8. Id. at 652 .

9. McMahen v. White, 30 Pa. Super. Ct. 169 (1906).

10. Id. at 173.

11. Supra note 6. 
many of the cases the court is obviously attempting to rationalize the result as the application of the doctrine of respondeat superior. ${ }^{12}$ In others the courts do not predicate liability upon that ground, but upon the ground that. the possessor, having, as such, an ability to control the driver, is under a duty to exercise reasonable care to do so. Thus in a Massachusetts case, ${ }^{13}$ the court said,

"When it appears that an owner of an automobile is riding in it while it is - being driven by another in an improper manner, and there is no evidence indicating a contractual surrender, nor evidence of an abandonment, of the owner's right to control it, the inference is warranted that the owner knew of and permitted its improper operation and thus became responsible for the consequences."14

The fact that in such cases the operator of the car is negligent has misled many courts to regard the liability of the owner and possessor as based upon the driver's negligence when it should, in most instances, be based both on the driver's negligence and the negligence of the possessor in failing to exercise care to prevent that negligent operation. It is to be observed that if the owner or possessor were liable for the negligence of the driver, it would be immaterial whether or not he "knew of" or "permitted" the improper operation of the vehicle.

The ordinary grounds of respondeat superior are seldom if ever available adequately to explain the possessor's liability in these cases. While the case of Sampson v. Aitchison might have been explained as a case of joint enterprise upon the theory that the driver and owner were mutually interested in the demonstration of the car, ${ }^{15}$ the emphasis in the opinion was placed upon the fact of possession by the defendant and the accompanying control over the driver. The formula of "control" is emphasized by nearly all the courts.

"Collins, when he took the wheel came under the control of the defendant. . .

12. See McMahen v. White, sutpra note 9, at 173; Beaudoin v. Mahaney, supra note 6; Doyon v. Massoline Motor Car Co., 98 N. J. L. 540, 120 Atl. 204 (1923). Of course, it is clear that some of the cases extend liability so that it is actually vicarious. Thus, in Doyon v. Massoline Motor Car Co., supra, and in Beaudoin v. Mahaney, supra, the holding seemed to be that the owner of the car whose agent was demonstrating it, was liable for the negligence of the prospective purchaser. who was driving it. These cases can all probably be explained as cases of joint enterprise. The same may be said for Sampson v. Aitchison, supra note 6. See Slater, J., in Brooke v. Bool, [1928] 2 K. B. 578, 585.

13. Wheeler v. Darmochwat, supra note 6.

14. Id. at 557,183 N. E. at 57 .

15. See Robison v. Oregon-Washington Rr. Co., 90 Ore. 490, 176 Pac. 594 (1918); Fisher v. Johnson, 238 Ml. App. 25 (1925). See Note (1929) 77 U. of PA. L. Rev. 676. 
If Collins had been going too quickly, and Sampson had told him to go slow, and Collins persisted in going too quickly, Sampson would have had the right to say to him: 'If you wish to continue to drive my car you must drive it as I direct, and if you will not do so you must cease to drive it.' In such circumstances Collins would have had to obey orders or cease driving."16

The "control" aspect of these cases is to be sharply distinguished from "control" as it is employed in the cases involving master and servant or joint enterprise. Control as the basis for the master's liability for the servant's negligence is obviously a fictitious control; the master is liable whether or not he in fact had any control over his servant. ${ }^{17}$ So too, in the case of a joint enterprise, the "joint control" of the parties seems primarily a convenient device whereby the extraordinarily difficult question whether one person should be held vicariously responsible for the negligence of the other can be passed by the judge to the jury. ${ }^{18}$ In the present problem, however, the word "control" is apparently honestly employed to indicate the fact that a driver of a vehicle will ordinarily comply with the wishes and directions of the owner of the car. "Control" is, therefore, used in a very real sense.

The rationale of this situation is indicated by the interesting comparison between the duty of the possessor of the vehicle to control the driving of a guest and the apparent lack of duty of a guest to control the driving of the owner so as to protect third persons. No case has been found in which a guest in a carriage or an automobile has been held liable to a third person injured by the owner's negligent driving for failing to control the driver. This is perfectly consistent with common sense. If $A$ is the gratuitous guest of $B$ in the latter's car, $A$ naturally feels reticent about offering suggestions and criticisms of $B$ 's driving. Such back-seat operation of a motor vehicle is not only commonly regarded as discourteous but is invariably resented by the owner of the car. On the other hand, if $B$, the owner, permits a guest to drive the car, $B$ does not feel the same reticence about warning of excessive speed or other dangerous operation, nor does the guest resent such suggestions. It is commonly felt that the fact of possession and ownership carries with it the privilege of direction and control of the manner in which the vehicle is operated. It is to be noticed, however, that a great mass of authority establishes the rule that even a gratuitous guest must protest against the driving of the owner if the guest is himself endangered there-

\footnotetext{
16. Sampson v. Aitchison, supra note 6 , at 850 .

17. As where the servant commits a tort while engaged in an act prohibited by the master.

18. See HARPER, op. cit. supra note $2, \S 148$.
} 
by. ${ }^{19}$ In other words, while the guest is under no duty to attempt to control the driving for the protection of third persons, he is under a very definite duty to attempt to control the driving for his own protection. ${ }^{20}$ But again the explanation is obvious. Even a gratuitous guest is felt justified in protesting against acts of the owner in driving the car if the guest is himself exposed to an unreasonable risk. This is a mere matter of self-defense against negligence. The situation is comparable to the rules governing self defense against another's conduct intended to injure the actor; the latter is always privileged to use reasonable force to protect himself from an attack. But the common law has not extended this privilege for the protection of third persons unless the person threatened is a member of the actor's family or is in some other way under his protection. ${ }^{21}$ If the actor intervenes to protect another not under his protection, he takes the risk that the other is privileged to defend himself. ${ }^{22}$ In other words, the actor under such circumstances has no privilege of his own but can avail himself only of such privilege as the person to whose aid he goes may have. It would seem clear that if there is no privilege to protect third persons from an assault, a fortiori there is no duty to protect them from mere negligent conduct. Thus it is that, just as there is no general privilege to assist third persons when threatened with the intentional infliction of bodily harm by another, there is no general duty to control another's negligent driving to protect third persons thereby exposed to harm, although there is such a duty to protect oneself.

It may be questioned whether this rule is peculiar to the operation of vehicles or whether it is safe to make generalizations. To be sure, the operation of an automobile is a particularly dangerous activity and this fact is, of course, of importance. It is suggested, however, that its importance lies only in the application of the standard of reasonableness, and not in the question of whether the possessor is under the duty to act as a reasonable man in an attempt to control the other's conduct. It is to be remembered that the courts have generally refused to place the automobile in a different legal category from other chattels solely be-

19. Crescent v. Anderson, 114 Pa. 643, \& Atl. 379 (1886); Bush v. Union Pacific Rr. Co., 62 Kan. 709, 64 Pac. 624 (1901); Cahill v. Cincinnati, etc., Ry. Co., 92 Ky. 345, 18 S. W. 2 (1891).

20. See cases collected in Note (1922) 18 A. L. R. 309, and Note (1927) 47 A. L. R. 293.

21. See, e.g., State v. Douglas, 115 S. C. 483, 101 S. E. 648 (1919); Gossett v. State, 123 Ga. 431, 51 S. E. 394 (1905); Sloan v. Pierce, 74 Kan. 65, 85 Pac. 812 (1906); Tompkins v. Knut, 94 Fed. 956 (C. C. D. Ky. 1899); Frew v. Teagarden, 111 Kan. 107, 205 Pac. 1023 (1922) ; Barfoot v. Reynolds, 2 Strange 953 (Eng. 1733).

22. Utterback v. Commonwealth, $105 \mathrm{Ky} .723,49$ S. W. 479 (1899); Obier v. Neal, 1 Houst. 449 (Del. 1857); Morris v. McClellan, 154 Ala. 639, 45 So. 641 (1908). But see -Warnack v. State, 3 Ga. App. 590, 60 S. E. 288 (1908). 
cause its use is more likely to cause accidents. ${ }^{23}$ It is quite obvious that a reasonable man will foresee danger from the operation of an automobile when there would be no recognizable risk from the use of other chattels and it is submitted that the principle involved in the cases under discussion is one which should receive general application.

\section{Relationship of Parent and Child}

The relationship of parent and minor child affords a sufficient basis for the affirmative duty on the part of the parent to exercise his parental control to prevent the child from intentionally or negligently harming others. Here again, the relationship does not make the parent liable as such. ${ }^{24} \mathrm{He}$ is, however, liable for his own torts, and this liability may arise out of the failure to perform definite acts to control the child when, as a reasonable parent, he should recognize that such control is necessary to prevent the child's injuring third persons. Again, these cases are to be distinguished from those in which the child is in fact the servant of the parent; in them the doctrine of respondeat superior is sufficient to impose liability upon the parent. ${ }^{25}$ A distinction is likewise to be drawn between the situation in question and that where the parent furnishes or turns over to his child a chattel which, in view of the child's immaturity, is likely to be so used that it will cause harm to others. In such a case, the relationship of parent and child is unimportant; liability would be imposed were it absent. Thus, a parent who furnishes his minor child with an automobile which he is incapable of driving with reasonable care is liable if the child negligently injures a third person; ${ }^{26}$ but he is also liable if he furnishes an automobile to an

23. See, e. g., the reluctance of courts to rest the results of the "family automobile doctrine" cases on the ground that an automobile is a dangerous instrumentality. Compare Southern Cotton Oil Co. v. Anderson, 80 Fla. 441, 86 So. 629 (1920), with Herr v. Butler, 101 Fla. 1125, 132 So. 815 (1931), and Engleman v. Traeger, 102 Fla. 756, 136 So. 527 (1931), as to which see Note (1932) 81 U. of PA. L. REv. 60 . And see Parker v. Wilson, 179 Ala. 361, 60 So. 150 (1912); Hartley v. Miller, 165 Mich. 115, 130 N. W. 336 (1911). Compare also the refusal of the New York Court of Appeals to base the liability of the manufacturer of an automobile to the ultimate user for negligence in its construction upon the ground that the automobile is inherently dangerous. McPherson v. Buick Motor Co., 217 N. Y. 382, 111 N. E. 1050 (1916).

24. Zeeb v. Bahnmaier, 103 Kan. 599, 176 Pac. 326 (1918); White v. Seitz, 342 Ill. 266, 174 N. E. 371 (1930); Norton v. Payne, 154 Wash. 241, 281 Pac. 991 (1929); Hulsey v. Hightower, 44 Ga. App. 455, 161 S. E. 664 (1931); Chaddock v. Plummer, 88 Mich. 225, 50 N. W. 135 (1891).

25. Teagarden v. McLaughlin, 86 Ind. 476 (1882); Hower v. Ulrich, 156 Pa. 410, 27 Atl. 37 (1893) ; Trahan v. Smith, 239 S. W. 345 (Tex. Civ. App. 1922).

26. Hopkins v. Droppers, 184 Wis. 400,198 N. W. 738 (1924); and see Note (1925) 36 A. L. R. 1164. 
adult stranger under similar circumstances. ${ }^{27}$ This liability of the parent arises from his active misconduct; he has actually created an unreasonable risk to others by placing a chattel in the hands of a person whose use thereof is likely to create a recognizable risk to third persons.

There is ample authority to sustain the imposition of such an affirmative duty. ${ }^{28}$ Thus, where a parent had knowledge of the habit of his minor child of beating other children with sticks, he was held liable because he had failed to exercise that control which a reasonable parent should have exercised to correct the child's vicious instincts. ${ }^{20}$ The parent had not furnished the child with the club with which he beat the plaintiff, the child was not performing any service for the father at the time, nor did the father actively participate in the child's misconduct. Liability was imposed because the father had failed to exercise care to correct the child's dangerous propensities. So too, in a recent case, a parent was held liable for an assault made by his child when it appeared that the parent had knowledge of the child's habit of bullying smaller children and had not taken reasonable steps to correct the evil. ${ }^{30}$ Said the court,

"While it is true that parents are not liable for torts committed by their minor children without their consent and knowledge, yet the principle applicable to the facts alleged in this case is that the parents are liable if it appears that they knew that their child was guilty of committing the particular kind of tort habitually . . . and made no effort to correct or restrain him." ${ }^{31}$

In a Wisconsin case, ${ }^{32}$ it was held that a father who had knowledge that his minor children were in the habit of scaring horses passing along the highway, was bound to use reasonable care so to control them as to prevent the plaintiff's horses from being frightened. Again, in an Ontario case, $^{33}$ a parent was held responsible to a plaintiff whose straw had been burned by the defendant's imbecile child when it appeared that the parent had knowledge of the child's propensity to play with matches and

27. Mitchell v. Churches, 119 Wash. 547, 206 Pac. 6 (1922).

28. Charlton v. Jackson, 183 Mo. App. 613 , 167 S. W. 670 (1914); Hoverson v. Noker, 60 Wis. 511,19 N. W. 382 (1884); Thibodeau v. Cheff, 24 Ont. L. R. 214 (1911); Stewart v. Schwartz, 57 Ind. App. 249, 106 N. E. 719 (1914); Daggy v. Miller, 180 Iowa 1146, 162 N. W. 854 (1917); Norton v. Payne, 154 Wash. 241, 281 Pac. 991 (1929); Ryley v. Lafferty, 45 F. (2d) 641 (D. Idaho 1930); and see Bollinger v. Rader, 153 N. C. $48 s, 69$ S. E. 497 (1910).

29. Norton v. Payne, supra note 28.

30. Ryley v. Lafferty, supra note 28.

31. Id. at 642 .

32. Hoverson v. Noker, supra note 28.

33. Thibodeau v. Cheff, supra note 28 . 
had failed to exercise the care required of him to prevent the child from playing near the straw. And in an Indiana case, ${ }^{34}$ a parent was held liable for failing to prevent his children from stretching a rope across a highway whereby the plaintiff, while bicycling, ran against the rope and was thrown to the ground.

In a number of these cases, it seems apparent that the courts are struggling to find the appropriate basis for liability. In many of them, the parent is connected with the tort of the child by his knowledge of the latter's propensities. This knowledge is referred to as an "acquiescence" or "consent" to the actual tort, ${ }^{35}$ although it is admitted that at the time thereof, the parent did not in fact know that the wrongful act was being committed. The fictitious character of this reasoning is obvious. It is an attempt to hold the parent by forcing the case within either the well-known rule that an actor who in any way participates in the commission of a wrong is a party to it, or that the "consent" to the wrongful acts, thus fictitiously inferred, constitutes an authorization to the child to act on behalf of the parent. However, consideration of the facts in these cases, together with the unanimity of results, argues strongly that the parent is held because he has failed to exercise the care which a reasonable parent should exercise to prevent his child from creating an unreasonable risk of harm to third persons.

In none of the cases is it suggested that a parent may be liable for his failure so to rear and train his child as to make it amenable to discipline. Parents might properly be horrified at the thought of being held legally responsible for the efficacy of their disciplinary measures. The issue of negligence, therefore, must be focused upon a particular failure of the parent to adopt reasonable measures to prevent a definite type of harmful conduct on the part of the child. General responsibility for the rearing of incorrigible children is not involved.

\section{Other Cases Where Defendant has Special Ability to Exercise Control Over Another}

There are other situations where there is involved the principle that a special relationship between two persons which gives the one a definite control over the actions of the other carries with it the duty to exercise that control in such a way as to protect third persons. A unique English case illustrates the principle in an extraordinary situation. ${ }^{36}$ The defendant was authorized by the plaintiff to go into the latter's shop at night when the plaintiff was absent to see that the place was secure.

\footnotetext{
34. Stewart v. Schwartz, supra note 28.

35. See Thibodeau v. Cheff; Norton v. Payne, both supra note 28.

36. Brooke v. Bool, supra note 12.
} 
On one occasion, the defendant took with him a friend who, detecting the odor of escaping gas, struck a match in an attempt to discover its source. An explosion resulted, damaging the plaintiff's goods. The defendant was held liable on the theory that his friend was present on the premises solely in the right of the defendant who thus had the peculiar ability to control his friend's conduct. His failure to exercise reasonable care so to do was a breach of a duty toward the plaintiff. "The defendant was in control of the enterprise," said the court. "It was only by his permission and at his invitation that Morris was in the shop, and he had a right to require Morris to leave the shop at any moment." "37

The relationship of master and servant, it seems, affords the master in some instances a peculiar ability to control the conduct of the servant even beyond the ambit of activity commonly designated as the scope of the employment. Some acts are so clearly disconnected with the purpose of the employment and so exclusively done by the servant on his own account that they are clearly not of a character such as to make the master liable under the doctrine of respondeat superior. Nevertheless, these acts may be so connected with the employment in time and place as to give the master a special opportunity to control the servant's conduct. In an interesting case decided by the United States Supreme Court, ${ }^{38}$ a defendant railroad company was held liable when a piece of timber thrown by a member of the crew of a passing train struck the plaintiff and caused serious injury. It appeared that the train crews frequently engaged in such conduct to the knowledge of the company and that, although they so acted entirely outside the scope of their employment, the company owed the duty to individuals to correct such dangerous conduct.

"It is not a question of scope of employment or that the act of the individual is performed by one who has ceased for the time being to be in the employment of the company. The question is, does the company owe any duty whatever to the general public, or, in other words, those individuals who may be in the streets through which its railroad tracks are laid, to use reasonable diligence to see to it that those who are on its trains shall not be guilty of any act which might reasonably be called dangerous and liable to result in injuries to persons on the street, where such act could by the exercise of reasonable diligence on the part of the company have been prevented." 39

The Court held that such a duty did exist. The New York Court of Ap-

37. Id. at 584 .

38. Fletcher v. Baltimore \& Potomac Rr. Co., 168 U. S. 135 (1897).

39. Id. at 140 . 
peals arrived at a similar result when it imposed liability upon the owner of a factory for failing to prevent his workmen from throwing articles out of the window at persons on the street below. ${ }^{40}$

Those who have special professional knowledge or skill may be so associated in the practice of their profession as to require that one exercise appropriate care to control the conduct of the other so as to avoid an unreasonable risk to third persons. And this is true although neither is the servant of the other and although neither is vicariously responsible for the negligence of the other under the "joint enterprise" formula. In a recent Idaho case, ${ }^{41}$ an action was brought against a surgeon for burns sustained by the patient when a hot water bottle was negligently left in her bed while she was still under an anesthetic. The evidence disclosed that the defendant had not himself handled the hot water bottle nor prepared the patient's bed; apparently the mistake had been that of. a special nurse, not the defendant's servant. He was held liable, however, because, being in control of the entire proceedings and in charge of the patient, it was his duty to exercise reasonable care to see that the patient was not exposed to risk of harm by the conduct of any of the persons attending her, whether independent contractors or not. The principle was recognized by a United States Circuit Court of Appeals ${ }^{42}$ in a case in which the defendant was in charge of the plaintiff during her confinement but another physician was called in for the delivery. After consultation it was agreed that the use of instruments was necessary and the other physician used the forceps, presumably without sterilizing them. The plaintiff was severely lacerated as a result of the operation and contracted blood poisoning. In stating the principles which determined the defendant's liability, the court explained:

"Two physicians, independently engaged by the patient and serving together by mutual consent, necessarily have the right, in the absence of instructions to the contrary, to make such a division of service as, in their honest judgment, the circumstances may require. Each must not only bring to the case the ordinary knowledge and skill of the profession, but also give his best personal attention and care ... Each, in serving with the other, is rightly held answerable for his own conduct, and as well for all the wrongful acts or omissions of the other which he observes and lets go on without objection, or which, in the exercise of reasonable diligence under the circumstances, he should have observed." 43

An obvious application of the principle under discussion would appear to be situations in which the defendant has control over another who

40. Hogle v. Franklin Manufacturing Co., 199 N. Y. 388, 92 N. E. 794 (1910).

41. Davis v. Potter, 51 Idaho 81, 2 P. (2d) 318 (1931).

42. Morey v. Thybo, 199 Fed. 760 (C. C. A. 7th, 1912).

43. Id. at 762 . 
is by reason of some social or mental maladjustment a dangerous person. Thus, those in charge of penitentiaries or insane asylums would seem clearly to come within this rule. It was so held in a Maine case ${ }^{44}$ in which the State was held liable in an action of tort when the superintendent of an insane hospital negligently liberated a patient who was dangerous to the community and who subsequently destroyed the plaintiff's property by fire. On the other hand, the problem is frequently confused by inappropriate discussion of proximate causation. Thus, the Louisiana court refused to impose liability upon the superintendent of an insane asylum for his negligent release of a patient afflicted with an incurable homicidal mania who subsequently killed the plaintiff's husband. ${ }^{45}$ The court thought that the defendant's negligence was not the proximate cause of the death. The fallacy here is obvious. There is ample support for the proposition that the negligent or criminal intervening act of another will not cut off the necessary causal relation between a defendant's negligence and a plaintiff's harm if the intervening criminal act was foreseeable by the defendant. ${ }^{46}$ Here the very risk which constitutes the defendant's negligence is the probability of such action. It is clear that when such action occurs, it should not insulate the defendant's negligence under the causation formula. In other words, it is clearly unsound to afford immunity to a negligent defendant because the intervening force, the very anticipation of which made his conduct negligent, has brought about the expected harm.

\section{Relationship of Defendant to Person Injured Persons Under Special Protection of Defendant}

Where a person is under the special protection of another, the latter is bound to exercise reasonable care to prevent harm to him, and this duty may include protection from the dangerous conduct of third persons. The relationship of parent and child is the obvious example of this situation. The problem here, however, is rendered largely academic because of the general incapacity of a child to recover from its parent for a tort against its person. ${ }^{47}$ If, however, the child is under the protection

44. Jones Co. v. State, 122 Me. 214, 119 Atl. 577 (1923). And see Missouri, Kansas \& Texas Ry. Co. v. Wood, 95 Tex. 223, 66 S. W. 449 (1902).

45. Cappel v. Pierson, 15 La. App. 524, 132 So. 391 (1931), as to which see (1931) 45 HARV. L. REv. 192.

46. St. Louis-San Francisco Ry. Co. v. Mills, 3 F. (2d) 882 (C. C. A. 5th, 1925); Bower v. New York Central Rr. Co., 91 N. J. L. 190, 103 Atl. 166 (1918); Fordon v. Bedand, 265 Mass. 40, 164 N. E. 734 (1929); Beatty v. Dunn, 103 Vt. 340, 154 Atl. 770 (1931); Marshall v. Caledonian Ry. Co., 1 Sess. Cas. 1060 (Scot. 1899).

47. Bulloch v. Bulloch, 45 Ga. App. 1, 163 S. E. 708 (1931); Smith v. Smith, 81 Ind. App. 566, 142 N. E. 128 (1924); McKelvey v. McKelvey, 111 Tenn. 388, 77 S. W. 664 (1903); Roller v. Roller, 37 Wash. 242, 79 Pac. 788 (1905). 
of a stranger who thus occupies the position of parent, the action may be maintained. ${ }^{48}$ Thus a child may recover from a guardian, stepparent or other person in loco parentis for failure to afford that protection which the law requires. The protection required in such a case includes protection against the dangerous activities of third persons, when it is reasonably necessary to the child's safety. An interesting Kentucky case well illustrates the point. ${ }^{49}$ Here a young girl was taken into a defendant's home to work for her board and for a small weekly sum while she attended school. The defendant's son, to the knowledge of the defendant but without any serious effort on the latter's part to restrain him, made advances to the girl and frequent excursions to the child's bedchamber. The father of the girl brought an action against the defendant for the child's seduction. The plaintiff's action was designated as one for breach of contract but the court held that the complaint stated a cause of action in tort as the defendant had been charged with negligence in failing to protect the girl under his care. "One who stands to a child in loco parentis," said the court, ${ }^{50}$

"has the same rights and duties during the continuance of that relationship as the parent and is bound to use the care incumbent upon a parent to shield such child from evil and injury ... It [the contract] was merely an undertaking to perform such duties as were incumbent upon them in the absence of a contract where they had the custody and control of an immature child. The contract merely recognized the immaturity of Isabel Cashen and the necessity on the part of those having custody and control of her to exercise the care and duty incumbent upon a parent to protect her ... A person standing temporarily in loco parentis may not shut his eyes to obvious danger threatening the moral or physical well-being of the child committed to his custody and plead nonliability when injury, due to his failure to exercise that degree of care incumbent upon him under the circumstances, results."

Where the custody of a person is by law entrusted to another under circumstances which deprive that person of the normal means of defending himself, there is a duty upon the one in charge to exercise reasonable care to afford protection to the other. Thus, the state, where it is responsible in tort, as well as sheriffs, wardens or other persons in charge of prisoners, is bound to exercise care to afford the protection to the prisoner from the dangerous conduct of third persons which the prisoner by reason of his incarceration is incapable of finding elsewhere. ${ }^{51}$

48. Treschman v. Treschman, 28 Ind. App. 206, 61 N. E. 961 (1901); Clasen v. Pruhs, 69 Neb. 278,95 N. W. 640 (1903).

49. Cashen v. Riney, $239 \mathrm{Ky} .779,40$ S. W. (2d) 339 (1931).

50. Id. at 341-343.

51. Logan v. United States, 144 U. S. 263 (1892); Indiana ex rel. Tyler v. Gobin, 94 Fed. 48 (C. C. D. Ind. 1899); Asher v. Cabell, 50 Fed. 818 (C. C. A. 5th, 1892); Hixon. 
Not only is the sheriff or jailor required to protect his prisoner against the violence of an infuriated mob when he has reason to believe that public opinion is incensed against the prisoner to the point where an attack is likely to be made upon him, ${ }^{52}$ but he must exercise reasonable care to afford him necessary protection against his fellow prisoners. Several cases have arisen in which a prisoner has been attacked by another inmate of the prison as a result of the "kangaroo" courts which have been tolerated from time to time in certain penal institutions. ${ }^{53}$ All these cases have placed emphasis upon the fact that the duty of reasonable protection to the prisoner must necessarily accompany his imprisonment and the ensuing inability to protect himself. It is clear that not only are there dangers peculiar to the imprisonment, but the prisoner is peculiarly helpless to protect himself from these dangers. Thus, the very fact that a person is imprisoned on a charge of certain offenses may so incite the passion of the community that he is in grave danger of mob violence. Again, incarceration with a group of persons who because of their social maladjustments are well known to have vicious and dangerous propensities, at once exposes a person to risks which are serious and obvious. The circumstances of the prisoner's arrest or confinement ordinarily make him utterly helpless to protect himself either by self-defensive means or by flight. The duty in such cases is, of course, only the duty to exercise reasonable care, and where a warden or jailor had neither the legal authority nor ability to obtain additional guards for the protection of his prisoner, he could not be found guilty of negligence in failing to do so. Even in such instances, however, he is bound to employ the ability which he has to give reasonable protection to those in his custody.

It has been held that the relationship of master and servant creates certain obligations on the part of the master to afford protection to the servant from certain dangers of the employment not included within the ambit of the risks assumed by the latter. Thus, the master has been held to be under a duty to administer first aid in an effort to mitigate the effects of bodily harm sustained by a servant in the course of the employment. $^{5 t}$ So too, the employer is said to be under a duty to

v. Cupp, 5 Okla. 545, 49 Pac. 927 (1897); Kusah v. McCorkle, 100 Wash. 318, 170 Pac. 1023 (1918) ; Eberhart v. Murphy, 110 Wash. 158, 188 Pac. 17 (1920); and see Ex parte Jenkins, 25 Ind. App. 532, 58 N. E. 560 (1900).

52. Logan v. United States; Indiana ex rel. Tyler v. Gobin, both supra note 51.

53. Hixon v. Cupp; Kusah v. McCorkle, both supra note 51 .

54. Ohio and Mississippi Ry. Co. v. Early, 141 Ind. 73, 40 N. E. 257 (1894); Rasch v. Elite Laundry Co., 98 Minn. 357, 108 N. W. 447 (1906); Harris v. Pennsylvania Rr. Co., 50 F. (2d) 866 (C. C. A. 4th, 1931), as to which see (1931) 30 MrCE. L. REv. 479 . And see also (1932) 17 CoRn. L. Q. 505. 
afford his servant protection against extremely inclement weather when the employment exposes the servant to unusual risks. ${ }^{55}$ And there are recent cases which impose upon the employer the duty either to protect or warn a servant of danger from the conduct of third persons where the danger arises out of the work. ${ }^{56}$ In one such case, the defendant railroad company was held liable for a failure to exercise reasonable care to advise a train guard in its employ of a train robbery of which it had been forewarned. Caught unaware by the robbers, the guard lost his life. It was true that the decedent knew the general risks of his work and assumed such risks in so far as they were an incident of his employment. By failing to warn him when it had knowledge of a specific peril, however, the defendant deprived him of the opportunity to which he was entitled in order to protect himself, and was properly held liable. Here again, the analogy of the privilege of the master to defend his servant against acts of third persons intended to harm the servant is helpful. Though having no independent privilege to defend others generally, an actor may defend his servant against an apparent assault without taking the risk that the servant is not privileged to defend himself. As to risks not known to the servant and not customary to the employment but arising out of it, the master seems under a duty to use reasonable care to warn the servant if he knows of danger or has peculiar knowledge thereof, and this includes threatened harm from the dangerous conduct of others.

\section{Carrier and Passenger}

There is abundant authority to sustain the liability of a carrier whose servants have failed to exercise reasonable care so to control the conduct of some of its passengers as to prevent either an intentional harm to other passengers ${ }^{57}$ or conduct which constitutes an unreasonable risk of harm to them. ${ }^{58}$ As early as 1865, the Supreme Court of Pennsylvania discovered that "the carrier is the protector by law of each passenger

55. Shoemaker v. St. Paul \& Duluth Rr. Co., 46 Minn. 39, 48 N. W. 559 (1891).

56. David v. Missouri Pacific Rr. Co., 328 Mo. 437, 41 S. W. (2d) 179 (1931), noted in (1932) 30 Micer. L. Rev. s06; St. Louis-San Francisco Ry. Co. v. Mills, 3 F. (2d) 882 (C. C. A. 5th, 1924).

57. New Orleans, St. Louis and Chicago Rr. Co. v. Burke, 53 Miss. 200 (1876); Brittor v. Atlanta \& Charlotte Ry. Co., 88 N. C. 536 (1883); Pittsburg, Cincinnati, Chicago \& St. Louis Ry. Co. v. Richardson, 40 Ind. App. 503, 82 N. E. 536 (1907) ; Cline v. MilwaukeeElectric Ry. \& Light Co., 146 Wis. 134, 131 N. W. 427 (1911); Koch v. Brooklyn Heights Rr. Co., 75 App. Div. 282, 78 N. Y. Supp. 99 (2d Dep't 1902); Murphy v. Western \& Atlantic Rr. Co., 23 Fed. 637 (C. C. E. D. Tenn. 1885); Flint v. Norwich \& New York Transportation Co., 34 Conn. 554 (1868); Pittsburg, Fort Wayne \& Chicago Ry. Co. v. Hinds, $53 \mathrm{~Pa} .512$ (1866).

58. Chicago, Terre Haute \& Southeastern Ry. Co. v. Fisher, 61 Ind. App. 10, 110 N. E. 240 (1916); Nute v. Boston \& Maine Rr. Co., 214 Mass. 184, 100 N. E. 1099 (1913). 
against the malice, the brutality or the drunkenness of his fellow travelers." Other courts soon followed in extending the duty to include not only protection against attacks and assaults in actual progress, but also the taking of precautions against harm whenever the carrier has reasonable ground for believing that violence is imminent. This duty today requires the carrier to exercise reasonable vigilance and supervision of passengers whose known character or condition is likely to make them a danger to fellow passengers. ${ }^{60}$

Corresponding to the duty to protect passengers against wrongdoers and co-extensive with it is the ancillary privilege on the part of the carrier to use force against the persons creating the disturbance or the risk of harm. ${ }^{61}$ This privilege not only justifies the carrier in either ejecting the offenders or restraining them until they can be turned over to police authorities when they are actually engaged in violence, but permits the carrier to control their conduct to prevent harm to other passengers at some future time. ${ }^{62}$ In the exercise of such privilege, the carrier must not, of course, employ excessive force against the offender and must use reasonable care not to expose other passengers to danger during the process of expelling the wrongdoer. ${ }^{63}$

In a few states, the carrier is not only bound to exercise reasonable care to protect its passengers from the conduct of others which threatens their bodily safety, but to protect them against conduct which is insulting and discourteous. ${ }^{64}$ This curious rule requires a carrier to protect its passengers against conduct which is not even tortious on the part of the persons indulging therein. The cases have for the most part been those in which a woman has been exposed to the ribald talk or profanity of the carrier's servants or her fellow passengers. This is really a direct protection of the interest in emotional tranquility-a protection which seems to be afforded only against carriers. It may be that a carrier should be required to furnish reasonably decent and comfortable, as well as rea-

59. Pittsburg, Fort Wayne \& Chicago Ry. Co. v. Hinds, supra note 57.

60. Cline v. Milwaukee Electric Ry. \& Light Co., supra note 57; Nute v. Boston \& Maine Rr. Co.; Chicago, Terre Haute \& Southeastern Ry. Co. v. Fisher, both supra note 58.

61. Baltimore, Pittsburgh \& Chicago Rr. Co. v. McDonald, 68 Ind. 316 (1879); Edgerly v. Union Street Rr. Co., 67 N. H. 312 (1892); Sorenson v. Lincoln Traction Co., 94 Neb. 91, 142 N. W. 702 (1913).

62. Vinton v. Middlesex Rr. Co., 93 Mass. 304 (1865); Berry v. Carolina, Clinchfield \& Ohio Ry. Co., 155 N. C. 287, 71 S. E. 322 (1911).

63. Thayer v. Old Colony Street Ry. Co., 214 Mass. 234, 101 N. E. 368 (1913).

64. Lucy v. Chicago, Great Western Ry. Co., 64 Minn. 7, 65 N. W. 944 (1896); Southern Ry. Co. v. Lee, 167 Ala. 268, 52 So. 648 (1910); Haile v. New Orleans Ry. \& Light Co., 135 La. 229, 65 So. 225 (1914); Philips v. Atlantic Coast Line Rr. Co., 160 S. C. 323, 158 S. E. 274 (1931). Contra: St. Louis, Iron Mountain \& Southern Ry. Co. v. Taylor, 84 Ark. 42, 104 S. W. 551 (1907). 
sonably safe facilities, but the cases seem not sufficiently numerous to draw far reaching generalizations, except perhaps when the insults are made by the carrier's servants themselves.

\section{Use of Land by Business Visitors}

The possessor or occupier of land who holds it open to business visitors is under the affirmative duty to see that the land is reasonably safe for the reception of such visitors or to use reasonable care to warn them of any unreasonably dangerous condition. ${ }^{65}$ A parallel duty is imposed upon the occupier of the land to use reasonable care to protect his business visitors not only from his own dangerous activity but from the conduct of third persons, whether other business visitors or trespassers. If the dangerous activity is conducted by the possessor's independent contractor or concessionaire, the possessor is under the duty of exercising reasonable care to control or regulate the conduct of the activity to prevent it from constituting an unreasonable risk to his business guests. ${ }^{66}$ Thus, in an early case the management of a public fair was held liable because a concessionaire conducted a shooting gallery at the fair in an unreasonably dangerous manner which resulted in the plaintiff's injury. ${ }^{67}$ The same duty is imposed upon the occupier to control the conduct of other business visitors upon his land. ${ }^{68}$ And indeed, a recent case has held the possessor liable when the risk was created by felonious trespassers on the premises. ${ }^{69}$

The duty in these cases, as in other cases of the duty of a possessor of land to his business visitors, is an alternative one. It can be discharged either by using reasonable care to protect the business guests against the dangerous activity of the wrongdoers or, where such is possible, by giving them warning adequate to afford the opportunity on their part of assuming the risk of harm or protecting themselves by leaving or remaining away from the land. ${ }^{70}$ In the absence of an adequate warning, however, the possessor of the land may not only be under the duty of using such ability as he has at the time to protect his business visitors, but if he

65. ToRts Restatedient, op. cit. supra note $4, \S 213$.

66. Id. § 214.

67. Conradt v. Clauve, 93 Ind. 476 (1883).

68. Exton v. Central Rr. Co., 62 N. J. L. 7, 42 Atl. 486 (1898); Mastad v. Swedish Brethren, 83 Minn. 40, 85 N. W. 913 (1901); Indianapolis Street Ry. Co. v. Dawson, 31 Ind. App. 605, 68 N. E. 909 (1903); Blakeley v. White Star Line, 154 Mich. 635, 118 N. W. 482 (1908); Moone v. Smith, 6 Ga. App. 649, 65 S. E. 712 (1909).

69. Sinn v. Farmers Deposit Savings Bank, 300 Pa. 85, 150 Atl. 163 (1930), as to which see (1931) 79 U. of Pa. L. Rev. 368.

70. Blakeley v. White Star Line; Indianapolis Street Ry. Co. v. Dawson, both supra note 68 . 
knows of the danger in advance, he must use reasonable care to be prepared to meet it when it becomes imminent. Thus, an Indiana case ${ }^{71}$ held that the management of an amusement park was under the duty of employing sufficient guards to maintain peace and order in the park and to protect its patrons, and that the fact that it had knowledge that a group of white men were conspiring to insult and attack negroes frequenting the park required the management either to warn the intended victims or to employ an additional number of police and guards. In the case of a common carrier, of course, it is frequently impossible to discharge the duty owed its patrons by a mere warning. This is true if the only way for a patron to avoid the risk is to forego or relinquish the service offered. In this respect, a carrier is in a position different from other business invitors. The duty imposed upon the carrier or other utility to furnish service to all members of the public prevents it from shifting the risk of harm from the dangerous activities of third persons to the patron by a mere warning. In such a case, the duty which the carrier owes to the public is to furnish it with reasonably safe service and this includes protection against the misconduct of third persons as well as protection against risks incident to the defective condition of the utility's equipment.

From the foregoing discussion, it appears that in two general types of situation a considerable number of cases have imposed an affirmative duty to control the conduct of third persons to prevent danger to others. In one type of case, the defendant has been in some special relationship with the person whose conduct he is required to control which gives him a peculiar ability to affect that person's conduct. In the other type, the defendant has been in some special relationship with the person threatened or injured which entitles that person to the protection of the defendant. Some of the cases discussed under the one or the other of these categories fall into rather well recognized groups; others represent unusual and rare fact situations. The policy, however, is not difficult to recognize in all of them. It is a dominant one in the law of torts and emphasizes again the relational character of tort law. Human beings by their activities have all sorts of dealings with each other and come into all sorts of relations. Some of these are tenuous, and to them the law attaches no special obligations. Others are regarded as of sufficient importance to require for a sound and stable social order certain assurances of safety to person and property on the part of the parties thereto. The social policies which determine what relationships require such special assurance and what ones are sufficiently unimportant not to require them are so incredibly complicated as almost to defy analysis. These

71. Indianapolis Street Ry. Co. v. Dawson, supra note 68. 
policies in the main reflect the general attitude of the community; they represent for the most part the popular notions of what constitutes proper assumptions on the part of one person when dealing with another. The common law attempts to interpret these communal reactions and to crystallize them into rules of law. As business and social relations become more and more complicated, these reactions are modified on the one hand and extended on the other. This requires modification and extension of the common law. The principles governing the duty of one person to control the conduct of another have this general elasticity which characterizes other principles of tort law. When, therefore, novel cases involving the problem arise, it will become the duty of the judges to examine the analogies of such cases as are discussed here and to determine whether, in the light of human experience as reflected in the decisions, the relations of the parties fall into one or the other of the general divisions mentioned. If, on the whole, it seems that it is not desirable to add to the number of fact situations falling within these two general divisions, no affirmative obligation will be imposed. If, on the other hand, the relationship of the parties appears to be, for all practical social purposes, indistinguishable from the type of cases which have been included under these general divisions, tort law may add another cubit to the stature which it has acquired over centuries of constant growth. 